\title{
Buddhist online communities on Vkontakte social network: structure, practices and ideas
}

\author{
Timur Badmatsyrenov ${ }^{1 *}$, Elizaveta Badmatsyrenova ${ }^{2}$, and Sanzhida Dansarunova ${ }^{1}$ \\ ${ }^{1}$ Buryat State University, Department of Sociology and Politology, 670000 Ulan-Ude, Russia \\ ${ }^{2}$ Buryat State University, Department of History and Theory of Law, 670000 Ulan-Ude, Russia
}

\begin{abstract}
Today, social networks have become a space for the active development of Buddhist online communities. In the new digital environment, new social forms of interaction between users are emerging, often with different ideas about Buddhism. Moreover, many of them are not integrated into offline Buddhist communities and practices. This process can be considered as the development of a digital religion, admixture of online and offline social structures, practices and ideas. The paper is aimed at identifying the characteristics of the structure of Buddhist communities on the VKontakte social network. We have used automated data collection and mathematical modelling methods to study the interaction between the existing online communities, identified and described the clusters of Buddhist users.
\end{abstract}

\section{Introduction}

Research on religion on the Internet has become an actively developing field of modern sociology. Over the past twenty years, this research field has evolved from the study of "cyber religion" as religious practices on computer networks to "digital religion", which manifests the differences between "real" and new "digital" religious structures. Famous American researcher Heidi Campbell identifies three waves in the development of digital religion studies [1]. The first wave was works on "cyber religion" that appeared in the 1990s as a result of the impact of information technologies and computer networks on religious behavior. The works of the second drew attention to the contradictions between real and virtual "spaces", which were manifested in "virtual religion" and virtual religious communities, practices that existed only in "cyberspace" and did not correspond to "real" religion. Christopher Helland proposed an idea of distinction between online religion and religion online to reflect the different ways of religious participation on the Internet [2]. He emphasized the flexibility and fluidity of online religion, which involve unlimited interactions between users, new forms of religiosity and interactive religious online practices. Religion online, in turn, includes online activities of traditional religious organizations and is aimed at informing users about their offline activities.

According to H. Campbell [3], the prevailing approach within current digital religion studies is consideration of the admixture of online and offline religious spaces and the development of hybrid forms of "digital religion". In this light, new forms of religion are developing on the Internet, and they are influenced by both offline and online religious space, religious communities under such conditions not only face the challenges of the digital environment, but also actively transform it.

H. Campbell's approach to the study of "religioussocial shaping of technology" is focused on the attitude of religious communities to offline and online communications, the Internet and media. There are following four stages in studying religious-social shaping of technology: the history and traditions of a certain religious community, the key religious doctrines, the analysis of the discourse of a religious community on new media technologies; the forms of digital media usage by religious communities. Religious groups form two main strategies in relation to new media conservative and innovative. They are historically rooted in traditional forms and define the trajectories of future media usage. An important part of the research is identifying key religious doctrines and patterns that influence the decision-making on the usage of new media, their appropriation or resistance [4].

While describing digital religion it is important to analyze how religious online communities as active agents in mediatization of religion are integrated. They represent a system of interactions between users of connected digital devices, websites, networking platforms and messengers focused on religious ideas, symbols and practices. In the early 1990s, the term "online communities" appeared to denote social associations that create and develop interactions by means of computer networks, arrange public discussions long enough to form "private networks" [5]. Heidi Campbell understands online religious community as a network of social relations, integrated by a set of common life practices, and reproduced through a shared history. A common understanding of religious ideas creates a basis for the conceptualization, shared by all members of the community, the core of which is a common faith and a search for meanings and purposes in 
the light of various interpretations of life and reality. $\mathrm{H}$. Campbell describes them as a system of multiple online and offline interactions between individuals and communities, new and old sources of authority and legitimacy, publicity and privacy, where people find themselves in the intersection of many religious networks and meanings.

To explain the contradictions of such "religious plurality", we address to the concept of Stewart Hoover and Nabil Echchaibi, in which they describe the admixture of digital culture and religious practice, resulting in a "third place" as a reflection of the transition from "religion digitalization" to a construction of religion through new media [6]. Churches, mosques and other places of worship play the role of "first place", while "second place" is individual religious practice. Social mediatized interactions in religious communities are becoming a multidimensional "third place", including manifestations of the "first" and the "second", and this makes the "in-between-ness" of their key characteristic. The "third place" has neither the autocratic traditionalism of conventional religious institutions, nor a blurred individualized religiosity. Religious third spaces are formed as self-referential communities, in which traditional religious ideas and practices are deconstructed, and their newly created interpretations gain legitimacy and authority. Heidi Campbell also appeals to the concept of "third place" to describe how digital religion emerges from the admixture and hybridization of everyday practices of "living religion" and digital culture.

\section{Digital Religion: History and Traditions of Online Communities}

The habitual categorization reflects the vision of Buddhism as a world religion, as a kind of the unity of communities, ideas and practices. In fact, Buddhism from the very beginning developed as a multitude of schools and versions, weakly related with each other, and the idea of the "world Buddhism" has arisen largely as a result of Orientalist construction. New media are becoming a field of the intersection of different Buddhist institutions and practices, ideas and beliefs, supported and transmitted by different communities and individuals.

Since the late 1990s, a multidisciplinary endeavor has been developed in foreign research that studies the connection between Buddhism, the Internet, and new media [7]. As L. Connelly notes, studying Buddhism on the Internet is a challenge in developing a new theoretical framework for describing the growing connection between religion and the Internet [8]. In 1994, Gary Ray coined the term "cybersangha" for denotation of new internet-based forms of religious communities [9]. In 2004, Charles Prebish identified three types of Buddhist Internet communities [10]. The first include the web pages of traditional Buddhist groups making their communication easier. The second type represents "virtual temples" created by traditional sanghas in addition to their activities. The third is "purely online communities" that does not exist offline.

Morten Schlutter describes two types of "Buddhist" Internet resources: websites, traditional ("pre-digital") Buddhist centers that have real places for meetings, meditations, discussions, and so on, and sites of cybersangha Internet communities, which members do not meet face-to-face [11].

Christopher Helland gives an interesting example: in 1996, Tibetan Buddhist monks from the Namgyal Monastery, recognizing the importance, significance, and potential of the Internet to support the Tibetan community in diaspora, used a variation of the Kalachakara Tantra to sanctify the newly created "cyberspace" as a giant mandala [12]. C. Helland believes that "official religious organizations and religious people", realizing the growing importance of the Internet, are trying to use it and practice their religion as they did in the past. "Informal religious groups and people on a religious quest" are engaging in online religious activities in a completely different, open way [13]. In this context, contradictions arise between the existing communities and the challenges from "multiple modernities" and "network individualism". Using "Virtual Tibet" as an example, he describes the creation of the Buddhist "third place" by the Tibetan diaspora as a hybrid community that not only allows entering online communities, but also strengthens network connections within Tibetans around the world and forms a common Tibetan Buddhist identity.

The activities of Buddhist researchers, often associated with their own religious practice, also contributed to the expansion of the "Buddhist" segment on the Internet. Besides, as Gregory Grieve notes, "romanticized Buddhist ideas have influenced the development of modern computer science from the very beginning"[14]. The largest researcher of American Buddhism, Charles Prebish, describes in detail the history of the ICT and computer networks influence Buddhist studies and the development of Buddhist communities since the early 1980s [15].

The plurality of digital Buddhism is a continuation of the Buddhist community heterogeneity, which is interpreted through the "two Buddhisms" model first formulated by the famous American scholar Charles Prebisch back in 1979. It dichotomously differentiates two distinct social aspects of Buddhist communities. The first involves Buddhists of Asian descent, "born in Buddhist cultural heritage", and the second - nonAsiatic converts [16]. The differences between these types of communities are determined by the sociocultural practices of individual socialization in a religious and cultural context. "Ethnic" Buddhism is more about communitarian and family structures, while "convert" Buddhism is more individualistic in nature.

In Russia, a similar situation of Buddhist community's multistructurality is developing, it is characterized by a combination of "ethnic" and "Europeanized" [17] Buddhists, dual development of "the religion of ethnic minorities or liberal intellectuals, as in other European countries" [18]. "Extra-ethnic" Buddhist converts in large cities often consider the 
"traditional" Buddhist clergy of Buryatia, Tuva and Kalmykia as ethnically narrow and do not perceive them as a sufficiently legitimate source of Buddhist explanation and certainty [19]. "Imaginary communities" of Russian Buddhists are constructed in several forms, including "traditional" monastic communities and related local communities of believers, communities of lay Buddhists. Many features of social organization, sociocultural and ethnic specifity of various Buddhist communities intersect in the online space.

Internet technologies have found strong supporters among many serious Buddhist figures. For example, the Buddhist Traditional Sangha of Russia, one of the largest Russian Buddhist organizations, is currently creating a complex digital ecosystem, which includes the primary information site "sangharussia.ru", a large number of sites of datsans, Zayayev Buddhist University, television, radio, mobile applications and communities in social networks. The head of the Buddhist Traditional Sangha of Russia Pandito Khambo Lama Damba Ayusheev is an active user of Facebook; he posts in his profile information of a very different nature, often concerning relevant social and political issues.

We should note that the Buddhist Traditional Sangha of Russia has been actively using the Internet for a long time. Thus, its website "datsan.buryatia.ru" was created in 2001, and in 2006 the largest Internet provider of the Republic of Buryatia "AK Mobiltelecom" together with the Ivolginsky Datsan issued special Internet cards that allowed followers not only to access the Internet and replenish personal accounts, but also to order a prayer service. The cards contained the phone number of roundthe-clock operator support, and it was possible to obtain the following information.

Today, Buddhist traditional sangha of Russia is developing an innovative strategy in relation to new media. Like any innovation, new media technologies meet an ambiguous perception in the Buddhist environment. Thus, such famous Buddhist figures as Dzongsar Khyentse Rinpoche and Alexander Berzin call their followers to apply Buddhist principles in social media. Both of them are active Internet users, they have pages on social networks, and run several well-known sites dedicated to the study of Buddhism and Buddhist practice.

Alexander Berzin, a Tibetologist, specialist in Buddhist studies and practitioner, in 2001 created the website "Berzin Archives" (www.berzinarchives.com), and its new version "www.studybuddhism.com". In his article, A. Berzin considers "how Buddhism can help increase benefits and reduce harm" from social media use [20]. He believes it is "good to set boundaries, whatever they may be, and keep them" to avoid addiction: "For example, using iPods you can listen to spiritual teachings, Dharma lectures, and so on, rather than the same music again and again, and then look for a new one. Try to use them wisely".

In 2013, Dzongsar Khyentse Rinpoche, a famous Buddhist teacher, filmmaker, head of several Buddhist centers, published "Social Media Usage Guidelines for So-Called Vajrayana Practitioners" on his Facebook page. In them, he calls for observing the requirements of
Buddhist tantric ethics and limiting network activity. Since there is a risk "to fall prey to "spiritual materialism," where the practice becomes just another fashion statement intended to adorn your ego and make you feel important, or have you feel that you're part of a "cool" social tribe, rather than to tame and transform your mind" [21].

A. Berzin and Dzongsar Khyentse Rinpoche see a danger for Buddhists in social media, because they can strengthen their egocentrism and harm spiritual practice. In addition, the publicity of social media violates the traditional esoteric system for transmitting Buddhist teachings and profanes sacredness, blurring the boundaries of the community.

And one more example, Sherete Lama of the Kurumkan Datsan "Gandan She Duvlin" Yeshi Namzhil Lama (Oleg Namzhilov) is an active user of VKontakte [22], Facebook [23], and Telegram [24]. There he publishes a lot of information about Buddhist philosophy and practice, Zurhai astrological forecasts and rituals. In addition, he publishes books, films and music videos about Buddhism.

In one of his publications, Yeshi Namzhil Lama associate the Internet activity of users with karmic consequences. He considers the activity on the Internet as acts of speech, and since publication on the open Internet can reach many people; this can significantly affect the karma of its author.

The Internet provides simply colossal opportunities for "earning" good karma. Public speaking gives faster results. But publications on the Internet will bear fruit a little later. They are not going anywhere; the law of karma always works. Just direct and written speech have different time of karma ripening [25].

$\mathrm{He}$ calls for politeness, attentiveness and restraint, since the results from swearing in comments on social networks can turn into extremely negative karmic consequences.

Tibetan Buddhist tantric practices are closely related to visual images, where visualization of deities or putting yourself in their form occupies an extremely important place. Traditionally, such practices require special preparation and commitment to follow them. Without them, there is a danger of "mishandling" these images, and this can be very harmful to the practitioner. As a result, in Buddhist online communities, there is often a particular concern about the threat of harm as a result of mishandling sacred texts and symbols.

Many of the activities on the web are oriented to offline events. Often they are fundraisings for building temples, monasteries and supporting monks. The motivation for donations is the calls to perform good deeds to create good karma.

The movement for abolition of Buddha Bars is one of the interesting examples of promoting online initiatives [26]; it included about a thousand users and had the form of online community. Several lay Buddhist activists launched a petition "Ban Buddha Bars Across Russia" on "Change.org" [27], which was signed by 7,734 people. They expressed their dissatisfaction with the entertainment establishments called "Buddha Bars" that exist in Russia and other countries, since they 
"improperly" use Buddhist symbols and attributes, and "such acts of public nature express willful disregard for society and are committed with the purpose of wounding religious feelings of Buddhists". This petition was sent to the President of the Russian Federation, the State Duma of the Federal Assembly of the Russian Federation, the General Prosecutor's Office and the Ministry of Culture of the Russian Federation. Based on this appeal, inspections were carried out, and as a result administrative proceedings were commenced in relation to a number of such establishments.

Defining the regulatory purview has become an important milestone for Buddhist online communities. Buddhist communities are often portrayed as nondogmatic and almost non-religious associations with indefinite membership based on individual choices. At the same time, the issues of legal regulation of social positions has always been important for Buddhist communities, which were arranged through a complex system of institutions and practices. According to Bato Dondukov, ideological differences and the "struggle for truth" have become key characteristics of the "Buddhist" segment on the Internet.

"The struggle for truth, which began with filtering out of non-Buddhist content, has further escalated into a conflict between Mahayana and Theravada Buddhists. The need for expansion and Theravada's broader possibilities for information activities allow it not only to claim equality with Tibetan Buddhism on the Internet, but also even to wage an information battle and make attempts to draw Buddhists over to its side. Web 2.0 Buddhism has become largely an environment for neophytes, and the few traditional Buddhists who got into this milieu, some of them have changed their Buddhist identity and the way they look at the functions and patterns of traditional Buddhism" [28].

Social networks and Buddhist forums often raise the questions about the acceptability of certain offline or online actions, up to questions about the permissibility of murder in computer games.

Users of the VKontakte social network, when filling out their profile in the category "worldview", can choose one of the options proposed by the developers, or their own option. The proposed options include Judaism, Orthodoxy, Catholicism, Protestantism, Islam, Buddhism, Confucianism, secular humanism, Pastafarianism.

According to the data obtained as a result of the system of queries in the VKontakte search engine, we have revealed a considerable increase in the number of users who chosen Buddhism as their worldview. In 2011, there were about 360,000 such profiles, and by August 2019 , their number exceeded 600,000 profiles. The studies of the religious situation and religiosity of the population in modern Russia, statements of politicians and media publications announce that there are 1-1.5 million Russian Buddhists; this figure is obtained by the mechanical sum of ethnic Buryats, Kalmyks and Tuvans, sometimes Altai and "new Buddhists". At the same time, as S. B. Filatov, and R. N. Lunkin note, "the data obtained from such a calculation rather testify to the scale of the claims of religious figures, politicians and national leaders" [29]. Online Buddhists as representatives of other religions are not taken into account in such calculations at all, although not all offline Buddhists are online ones and vice versa, and this requires at least additional research.

Translation of "worldview" occupies a significant place in the online activity of many users. Religious online practices are an important component in the development of Buddhist online communities. In addition to "educational" and proselytic information about Buddhist rituals and cults, new forms have emerged on the Internet like online streams of Buddhist teachings, online prayers and "improvement" of karma by reposting images of Buddhist deities, mantras or even the content of "Buddhist" public pages.

This picture has spread throughout the Internet. They say that when you are looking at it, and making a wish, it will come true in 2-3 days. It came true for me. Post it on your wall and try yourself [30].

Construction and online promotion of sacred objects, ideas and practices have become the key areas of filling the online space with religious content. The Internet and social networks are turning into a space of sacred action for Buddhist practitioners, network behavior becomes a part of religious practice, and online activity opens the way of reaching salvation and receiving punya (merit). At another point, there is an opposite tendency towards "secularization", profanation of Buddhist ideas and practices, when refined philosophical teachings and secret practices come into a wide and diverse audience of social networks.

In the communities dedicated to objects of religious worship or profiles of religious leaders, the user can easily receive "direct" messages with religious content from them and / or send them his own messages. Among the profiles registered on VKontakte, one can find a large number of profiles of Buddha, Christ or other divine beings. For example, the construction of a new cult of Pandito Khambo Lama Itigelov (Etigelov) is actively supported in the media and social networks. The community "Khambo Lama Dashi-Dorzho Itigelov" [31] on VKontakte is an example of the media activity of Buddhist religious professionals in Buryatia, through whose efforts a profile of a transcendental character was created on social networks. Network activity is carried out on his behalf, as well as messages, video and photo are transmitting. In that way a specific sacralized space for the legitimization of Pandito Khambo Lama D.-D. Itigelov is constructed where he receives recognition and support from users:

Social networks have blurred and transformed the boundaries between the sacred and the profane by opening up a wide field for the "simulation" of the sacred. A special space arises in them, in which interactions between online groups and virtual personalities of users take place; their participants can be also the objects of religious worship [32].

One of the most interesting developments in Buddhist communities on social media has been the reformatting of traditional religious hierarchies. The key role in this process was played by the learned monks, integrated into formalized hierocratic structures with a 
monopoly on the production and transmission of religious knowledge. In the traditional Buddhist social structure, laypeople predominantly occupied the position of consumers of religious practices, transmitted by priests. Currently, the significant changes are taking place in traditional religious structures; they are manifested in the activity in social networks of priests and lay Buddhists from different regions of the world, representing various Buddhist schools.

\section{Conclusion}

Social media is becoming the field for the integration of an individual into a religious community according to several scenarios. At the same time, if in offline communities the integration of believers, as a rule, presupposes direct interaction, and formation of local groups, then online communities are extraterritorial and one can join them from anywhere in the world. Stig Hjarvard drew attention to the contrariety of the processes of mediatization and secularization, which is manifested in the fact that the growth of religion representation in the public media is not accompanied by the revival of organized religion [33]. Despite the increasing media attention to religious issues, institutionalized religious communities are losing ground, giving way to individualized practices and beliefs. At the same time, the Internet and popular culture provide relatively free access to lot of symbols, a kind of "bazaar of meanings", superficial cultural references in a simplified and not always reliable form, which individuals use for construction of their own religious microworlds.

Along with this, social media and digital religious communities are becoming a form of social integration in both global and local dimensions. Media has become a field for the construction and support of "imaginary" religious communities, forming their digital topology, in which users reproduce religious activities, like "the outer limits of the old religious communities of the imagination were determined by which pilgrimages people made" [34].

\section{Acknowledgments}

The study was supported by the Russian Foundation for Basic Research within the framework of scientific project No 20-011-00531

\section{References}

1. H. Campbell, Surveying Theoretical Approaches within Digital Religion Studies.

2. C. Helland, Online Religion as Lived Religion Methodological Issues in the Study of Religious Participation on the Internet. Online - Heidelberg Journal of Religions on the Internet. Volume 01.1 Special Issue on Theory and Methodology, p.1-16. (2005) [http://archiv.ub.uniheidelberg.de/volltextserver/5823/1/Helland3a.pdf, accessed 12.04.2019]
3. H. Campbell, Surveying Theoretical Approaches within Digital Religion Studies", New Media and Society. Volume: 19 issue: 1, pp. 1-10. (2016)

4. H. Campbell "When Religion Meets New Media". New York: Routledge, p.97 (2010)

5. H. Rheingold, The Virtual Community, New York: HarperPerennial. p. 5. (1993)

6. S. Hoover and N. Echchaibi Finding Religion in the Media-Third Spaces of Digital Religion, a Working Paper in the Center for Media, Religion and Culture. University of Colorado (2012).

7. R. Hayes, The Internet as a Window onto American Buddhism. American Buddhism: Methods and Findings in Recent Scholarship. (1999)

R. Williams and Q. Christopher. eds. American Buddhism: Methods and Findings in Recent Scholarship, Richmond, Surrey, UK: Curzon Press, p. 168-179 (1999) Greider B. Academic Buddhology and the CyberSangha: Researching and Teaching Buddhism on the $W e b$. Teaching Buddhism in the West: From the Wheel to the Web. Ed. by V. Nori, R. Hayes, J. Shields. London. New York. p. 212-234 (2002)

Buddhism, the Internet, and Digital Media. The Pixel in the Lotus Ed. by Gregory Price Grieve, Daniel Veidlinger. New York: Routledge. 240 p. (2014)

Digital Humanities and Buddhism: An Introduction Ed. By D. Veidlinger, De Gruyter. (2019).

8. L. Connely, Virtual Buddhism: Online Communities, Sacred Place and Objects - The Changing World Religion Map: Sacred Places, Identities, Practices and Politics. Springer Netherlands, pp. 3869-3882 (2015).

9. G. Ray, A Resource Roundup for the Cybersangha. Tricycle: The Buddhist Review. 3(4), pp. 60-63. (1994)

10. Ch. S. Prebish, L. L. Dawson, D.E. Cowan, "The Cybersangha: Buddhism on the Internet". Religion online: Finding faith on the Internet. p. 145. London: Routledge. (2004)

11. M. Schlutter, M. Poceski, Buddhism in the Digital World. The Wiley Blackwell Companion to East and Inner Asian Buddhism, pp.511, Chichester, UK: John Wiley. (2014)

12. C. Helland Virtual Religion: A Case Study of Virtual Tibet. Oxford Handbooks Online. p. 4. (2015) https://www.oxfordhandbooks.com/view/10.1093/oxford hb/9780199935420.001.0001/oxfordhb-780199935420e-43.

13. Ibid, p. 8 .

14. G.P. Grieve, D. Veidlinger, Buddhist Media Technologies. The Oxford Handbook of Contemporary Buddhism. New York: Oxford University Press, p. 476. (2016)

15. C. Prebish, Online Peer-Reviewed Journals in Buddhism. The Birth of the Journals of Buddhist Ethics and Global Buddhism. Buddhism, the Internet, and Digital Media. The Pixel in the Lotus. New York: Routledge, p. 79-92. (2014)

16. P. Numrich, Two Buddhisms Further Considered. Contemporary Buddhism, 4(1), p. 55 (2003).

17. B. U. Kitinov, Buddizm $v$ identifikatsionnykh protsessakh u rossiyskikh buddistov. [Buddhism in the Identification Processes of Russian Buddhists]. Religiya 
$\mathrm{v}$ samosoznanii naroda (religioznyy faktor $\mathrm{v}$ identifikatsionnykh protsessakh). Moscow: Institute of Sociology RAS, pp. 214-230. (in Russ.) (2008)

18. N.V. Tsyrempilov, Buddizm v Rossii: proshloye $i$ nastoyashcheye [Buddhism in Russia: Past and Present]. Vlast. 4, pp. 83-87. (in Russ.) (2013)

19. A. S. Agadzhanyan Buddizm v sovremennom mire: myagkaya alternativa globalizmu [Buddhism in the Modern World: A Soft Alternative to Globalism]. Religiya i globalizatsiya na prostorakh Evrazii Ed. by A. Malashenko i S. Filatova. Moscow: Neostrom, p. 228. (in Russ.) (2005)

20. A. Berzin Kak primenyat buddiyskiye printsipy $v$ vek sotsial'nykh setey [How to Apply Buddhist Principles in the Era of Social Networks]. Available at: https://studybuddhism.com/ru/prodvinutyyuroven/istoriya-i-kultura/buddizm-v-sovremennommire/kak-primenyat-buddiyskie-printsipy-v-veksotsialnyh-setey (accessed 28.11.2017).

21. Dzongsar Khyentse Rinpoche. Pravila polzovaniya sotsial'nymi setyami dlya tak nazyvayemykh praktikov Vadzhrayany [Social Media Guidelines for So-Called Vajrayana Practitioners]. Available at: http://savetibet.ru/2013/01/20/dzongsar_khyentse.html (accessed 28.11.2017).

22. Kurumkansky datsan. Available at: https://vk.com/kurumkan.datsan (accessed 28.02.2021)

23. Kurumkansky datsan. Available at: https://www.facebook.com/groups/kurumkan.datsan (accessed 28.02.2021)

24. Kurumkansky datsan. Available at: https://t.me/kurumkan_datsan (accessed 28.02.2021)

25. Dobrodeteli i grekhi interneta [Virtues and Sins of the Internet]. Available at: https://vk.com/feed?w=wall$73340092 \_14034$ (accessed 28.02.2021)

26. https://vk.com/ban_buddha_bars

27. Zapretite Budda Bary po vsey Rossii! [Ban All Buddha Bars Across Russia!]. Available at: https://www.change.org/p/\%D0\%B7\%D0\%B0\%D0\%BF $\% \mathrm{D} 1 \% 80 \% \mathrm{D} 0 \% \mathrm{~B} 5 \% \mathrm{D} 1 \% 82 \% \mathrm{D} 0 \% \mathrm{~B} 8 \% \mathrm{D} 1 \% 82 \% \mathrm{D} 0 \%$
B5-\%D0\%B1\%D1\%83\%D0\%B4\%D0\%B4\%D0\%B0$\% \mathrm{D} 0 \% \mathrm{~B} 1 \% \mathrm{D} 0 \% \mathrm{~B} 0 \% \mathrm{D} 1 \% 80 \% \mathrm{D} 1 \% 8 \mathrm{~B}-$

$\% \mathrm{D} 0 \% \mathrm{BF} \% \mathrm{D} 0 \% \mathrm{BE}-$

$\% \mathrm{D} 0 \% \mathrm{~B} 2 \% \mathrm{D} 1 \% 81 \% \mathrm{D} 0 \% \mathrm{~B} 5 \% \mathrm{D} 0 \% \mathrm{~B} 9-$

$\% \mathrm{D} 1 \% 80 \% \mathrm{D} 0 \% \mathrm{BE} \% \mathrm{D} 1 \% 81 \% \mathrm{D} 1 \% 81 \% \mathrm{D} 0 \% \mathrm{~B} 8 \% \mathrm{D} 0 \%$

B8

28. B. Ts. Dondukov, Nekotorye podkhody $k$ tipologizatsii buddiiskogo segmenta Interneta [Several Approaches to the Typology of the Buddhist Segment of the Internet]. Media Philosophy XIII. The Universe of Digital Mind: New Territories of Meaning. St. Petersburg Philosophical Society, Saint Petersburg, p. 192. (in Russ.) (2017)

29. S. B. Filatov, R. N. Lunkin Statistika rossiyskoy religioznosti: magiya tsifr $i$ neodnoznachnaya realnost [Statistics of Russian Religiosity: The Magic of Numbers and an Ambiguous Reality]. Sotsiologicheskie issledovaniya — Sociological Studies. 6, p. 35 (in Russ.).

30. Khambo Lama Dashi-Dorzho Itigelov. Available at: $\quad$ https://vk.com/etigelov?z=photo48005_456239860\%2Falbum-48005_00\%2Frev accessed 11.10.2019)

31. Khambo Lama Dashi-Dorzho Itigelov. Available at: https://vk.com/etigelov (accessed 14.02.2020).

32. T. B. Badmatsyrenov, M. V. Skvortsov, F. V. Khandarov, Buddiyskie tsifrovyye praktiki transtsendentnosti: VK-soobshchestvo "Khambo Lama Dashi-Dorzho Itigelov" [Buddhist Digital Practices of Transcendence: VK-community "Khambo Lama DashiDorzho Itigelov]. Monitoring obshchestvennogo mneniya: Ekonomicheskie i social'nye peremeny [Monitoring of Public Opinion: Economic and Social Changes] No.2. p. 340. (2018)

33. S. Hjarvard, Three Forms of Mediatized Religion: Changing the Public Face of Religion, p. 22 (2020)

34. B. Anderson Imagined Communities: Reflections on the Origin and Spread of Nationalism. Verso, 256 p. (2016) 